\title{
20 I I Report From the Student Affiliates of Seventeen (SAS)
}

The Counseling Psychologist 40 (I) $181-182$

(C) The Author(s) 2012

Reprints and permission: http://www. sagepub.com/journalsPermissions.nav DOI: 10.1 I77/001 I00001 |430943 http://tcp.sagepub.com

@SAGE

\section{Melanie M. Lantz and Katharine S. Shaffer}

The Student Affiliates of Seventeen (SAS) is the student-run representative body for the Society of Counseling Psychology (SCP) student members. Our primary purpose is to keep student members informed of current events in SCP and APA, and to represent the collective student voice to SCP. SAS is currently hosted by the University at Albany Counseling Psychology doctoral program, and we have just concluded our first of three years as the host institution. Our 15-member executive board has worked hard during our initial transition year, and we are excited to share our accomplishments and vision for our term with TCP readers.

As the host institution, the pillars we chose to support our mission are Scholarship, Professional Development, Diversity, and Social Justice and Advocacy. We believe these are central to the identity of Counseling Psychology and intend for them to guide us through our three-year term. Earlier this year, the SAS Executive Board provided a two-part presentation at Lehigh Carbon Community College entitled What is Counseling Psychology? and How to Get into Graduate School in Psychology. This presentation was created to educate undergraduate students about Counseling Psychology, as well as other fields in psychology and to help students better navigate graduate school applications. We will continue these outreach presentations and will provide these materials to other SAS members to present in their communities to support interest and growth in professional psychology.

In addition, we are excited to announce the 20th Annual Diversity Conference co-hosted by SAS and the Department of Counseling Psychology at the University at Albany. This year's conference entitled Exploring Privilege: Understanding and Using Our Voices will explore both scientist and practitioner perspectives on privilege. For the first time, we will host student poster sessions and will also host a seminar on positive psychology and well-being via Skype. The conference will be held at the University at Albany in November 2011, and we look forward to meeting more SAS members! Please look for our call for proposals for the poster session. 
At APA this year, SAS hosted two great program hours-The Future of Counseling Psychology, a discussion hour with Dr. Y Barry Chung and Dr. Linda M. Forrest, and Helping Students Explore Privileges During Their Graduate Training, with Dr. Rebecca L. Toporek. The programs were wellattended and informative. Also at APA, SCP Buttons were available, which were designed by a SAS member as part of a SAS/SCP contest.

We are appreciative of how important SCP considers its student members, and how much they encourage student participation. So far, we have assisted in placing student members on SCP Committees such as the Hospitality Space Committee, the Awards and Recognition Committee, and, most recently, have assisted in placing student members on SCP Special Task Groups (STGs). Candice Crowell from Howard University is working with Dr. Y Barry Chung, SCP President, on his Leadership Academy STG, and Ren Hong, from Oklahoma State University, is also working with Dr. Chung on his What is Counseling Psychology? Video STG. Leadership opportunities are abundant for students in SCP, and we look forward to sharing this experience with even more students by getting them involved with SAS and SCP.

In order to encourage student involvement in SCP and APA, we intend to focus the remainder of our term on fostering a sense of community amongst Counseling Psychology students nationally. So far, our network coordinators have reached out to program and regional SAS representatives via conference calls, and we intend to continue these. We are developing ways to increase the sense of community amongst students and look forward to communicating these to students in the near future. We will continue to be guided by our pillars and believe that creating a stronger community of Counseling Psychology students is integral to any future endeavors we here at the University at Albany intend to implement. We encourage SAS members to contact us with their ideas and to get involved.

This opportunity to serve both SCP Leadership and SAS members nationally is truly a privilege, and we appreciate the support we receive from both SCP and the SAS membership. We look forward to sharing our exciting community-building ideas with everyone soon, and to meeting more students as we continue to engage the membership. Please watch our newsletter and our listserv for opportunities, and always feel free to contact us-we have an open-inbox policy! Thank you, from the entire SAS Executive Board at the University at Albany.

Melanie M. Lantz,m1935175@albany.edu

Katy Shaffer,xkat@inbox.com 